\begin{tabular}{|l|l|l||}
\hline \multicolumn{2}{|c|}{ PublisherInfo } \\
\hline \hline PublisherName & $:$ & BioMed Central \\
\hline \hline PublisherLocation & $:$ & London \\
\hline \hline PublisherImprintName & $:$ & BioMed Central \\
\hline \hline
\end{tabular}

\title{
Mammals feed off yeast pathway
}

\begin{tabular}{|l|l|l||}
\hline \multicolumn{2}{|c|}{ ArticleInfo } \\
\hline \hline ArticleID & $:$ & 5070 \\
\hline \hline ArticleDOI & $:$ & $10.1186 /$ gb-spotlight-20050321-01 \\
\hline \hline ArticleCitationID & $:$ & spotlight-20050321-01 \\
\hline \hline ArticleSequenceNumber & $:$ & 46 \\
\hline \hline ArticleCategory & $:$ & Research news \\
\hline ArticleFirstPage & $:$ & 1 \\
\hline \hline ArticleLastPage & $:$ & 4 \\
\hline \hline & & RegistrationDate : 2005-3-21 \\
\hline ArticleHistory & $:$ & OnlineDate \\
\hline \hline ArticleCopyright & $:$ & BioMed Central Ltd2005-3-21 \\
\hline \hline ArticleGrants & $:$ & \\
\hline \hline ArticleContext & $:$ & 130596611 \\
\hline \hline
\end{tabular}




\section{Melissa Lee Phillips}

Email: mlp@melissaleephillips.com

The biochemical pathway that senses amino acid deficiencies in yeast is also at work in mammals, researchers report in this week's Science. While this signaling initiates amino acid synthesis in yeast, it alters eating behavior in rats, according to senior author Dorothy Gietzen of the University of California, Davis.

"What's most striking to me, because I'm a yeast geneticist, is that you'd be able to see this effect on feeding behavior," Alan Hinnebusch of the National Institutes of Health, who was not involved in the study, told The Scientist.

In yeast, a deficiency of a particular amino acid causes an accumulation of that amino acid's corresponding transfer RNA. This free tRNA — called "uncharged" because it is not attached to an amino acid-activates the kinase GC nonderepressing 2 (GCN2), which then phosphorylates eukaryotic initiation factor 2 alpha (eIF-2alpha). This signal decreases the yeast's global protein synthesis and increases transcription of genes that synthesize deficient amino acids.

Gietzen, postdoc Shuzhen Hao, and their colleagues wanted to see if uncharged tRNA was responsible for the rat behavior that seems like a sort of behavioral homolog of this pathway. Rats will normally spend 30-45 minutes eating, if they haven't eaten for a while before that. Beginning at about 20 minutes, researchers have shown that rats eating food deficient in essential amino acids will eat less than those eating normal food, Gietzen explained.

The team directly inhibited tRNA charging in rats by injecting amino alcohols-alcohol derivatives of amino acids - into the anterior piriform cortex, a brain region that projects to feeding circuits and has long been known to sense amino acid deficiencies. Amino alcohols are selective, potent inhibitors of the synthetases that join amino acids with their respective tRNAs, Gietzen said.

About 20 minutes after receiving injections of the amino alcohol L-threoninol, the rats began to eat less food than normal, as if they were eating food with no threonine, Gietzen said. After injections of Lleucinol, they also ate less than control rats.

Injections of alcohol derivatives of the dispensable amino acids serine and proline, however, did not affect the rats' feeding. Also, the stereoisomer D-threoninol did not change their food intake, presumably because it doesn't interfere with charging of mammalian amino acids, which are all $\mathrm{L}$ isomers, Gietzen said.

Using amino alcohols to reduce amino acid sensing shows that uncharged tRNA is likely the activating ligand, just as in yeast, said Hinnebusch.

To connect GCN2 - the kinase activated by uncharged tRNA in yeast - and eIF-2alpha to feeding behavior, Gietzen and colleagues examined GCN2-null mice. When wild-type mice ate food completely devoid of threonine, eIF-2alpha phosphorylation increased, but this effect was absent in GCN2 knockouts. Also, when given a choice, wild-type mice ate normal food significantly more often than food with no threonine; mice without GCN2 showed no preference. 
"Although GCN2, based on the yeast homolog, was known to respond to nutrient deprivation, its precise role in mammals was a puzzle," Ruchira Sood of Stanford University told The Scientist in an Email. "This is an interesting connection."

"It fits perfectly with everything else that's been done in yeast that these alcohol treatments are leading to uncharged tRNA and that's activating GCN2 and eIF-2 phosphorylation," said Hinnebusch.

However, he is "a bit skeptical" that Gietzen and her colleagues can be sure that GCN2 is responsible for changes in feeding behavior. The data suggesting that GCN2-null mice do not recognize an amino acid-deficient diet do not reveal "that big of a difference," Hinnebusch said. In addition to measuring the knockouts' response to threonine-devoid food, "it would have been nice to repeat it using some of the alcohols," Hinnebusch said.

"How eIF-2 phosphorylation leads to rejection of certain foods is open to speculation," according to Sood, who was not involved in the study.

Phospo-eIF-2alpha likely induces piriform neuron firing through calcium signaling, Gietzen said, but no one has pinned down how exactly that might happen. "That's the hole in our story," she said, but "we've at least got the initial signaling mechanism."

\section{References}

1. S. Hao et al., "Uncharged tRNA and sensing of amino acid deficiency in mammalian piriform cortex," Science, 307:1776-8, March 18, 2005., [http://www.sciencemag.org]

2. Dorothy Gietzen, [http://faculty.vetmed.ucdavis.edu/faculty/dwgietzen/]

3. Alan Hinnebusch, [http://eclipse.nichd.nih.gov/nichd/lgrd/bio_hinnebusch.htm]

4. T.J. Koehnle et al., "Rats rapidly reject diets deficient in essential amino acids," J Nutr, 133:2331-5, July 2003.

5. P.M. Leung, Q.R. Rogers, "Importance of prepyriform cortex in food-intake response of rats to amino acids," Am J Physiol, 221:929-35, September 1971.

6. Ruchira Sood, [http://med.stanford.edu/profiles/frdActionServlet?choiceId=facProfile \&fid=5877]

This PDF file was created after publication. 